might be due, not to meat as such, but simply to the want of other necessary elements, deficient under the conditions of his experiments, but not deficient in an ordinary mixed diet, and aware that in this respect the experiments were possibly a repetition of the classical ones of Chossat, Förster, and others, it is remarkable that Dr. Chalmers Watson should have ventured freely to apply the results to man, without having either mentioned or excluded this possible fallacy.

Dr. Watson is quite right in supposing that the main part of my remarks at the Pathological Society referred to the bone changes.

I regard the experiments with great interest and do not wish to minimise their value, but hold that, until the causation of the results is more exactly known, their application to modern human dietetics is unjustifiable, and discussion fruitless. I am, Sirs, yours faithfully,

London, W., Feb. 4th, 1907. EDMUND I. SPRIGGS.

To the Editors of THE LANCET.

SIRs, - There is one fact which points to the conclusion that the deficient assimilation of lime has some effect in determining early caries. The teeth in children who are the subjects of rickets are not only late in erupting but also undergo early decay. In this disease we know that the bones are soft from a deficiency of lime salts, and it would appear probable that the early dental decay may be associated with a similar deficiency of lime salts in the teeth. I am, Sirs, yours faithfully,

Nottingham, Jan. 29th, 1907.

F. H. JACOB

\section{MILK IN SMALL GENERAL SHOPS.}

\section{To the Editors of THE LANCET.}

SIRs,-Some years ago when at Surbiton I was called to see a young lady living in a good house who was suffering from diphtheria. I carefully examined the various pipes, traps, water-supply, \&c., but could find nothing to account for its occurrence. On leaving the house I met the medical officer of health and told him about the case and my suspicions. When I gave him the name of the dairy he altogether discountenanced my suspicions, saying he knew the persons who kept it and that they were particularly careful and clean. However, as we parted he was met by the rural medical officer ô health and asked by him to see two cases of diphtheria which had broken out in a very large house on the hill. After seeing these cases he inquired as to the dairy from which the milk-supply was obtained and when he found it to be the same as the one mentioned by me the two medical men at once visited the dairy in question and found the woman who served the milk nursing a girl who had been brought down from London suffering from diphtheria in a room adjoining the shop. The selling of the milk was at once stopped and no other case of diphtheria arose. Such a thing as this would never have occurred in a large well-ordered business. I may add that the whole credit of discovering the cause in this instance was awarded to the medical of incer of health. I am, Sirs, yours faithfully,

Bexhill-on-Sea, Feb. 2nit, 1907

F. P. ATKINSON.

\section{MEDICAL LAW REFORM AND QUACKERY. \\ To the Editors of THE LANCET.}

SIRS,-Will you allow me to bring forward in your columns the suggestion $I$ have already published-namely, that the united efforts of the profession should be directed towards promotion of a Royal Commission to inquire into the whole subject of medical law, into the practice of the profession by unqualified pretenders, and into the trade in quack medicines? I would urge the following brief statements in support of $\mathrm{my}$ proposition. To justify them fully would occupy some pages of your space; they will not, I believe, be disputed by anyone having adequate knowledge of the question. The profession is entitled to at least the same amount of protection as the law affords to solicitors. It is impossible for an unqualified person to practise with impunity as a solicitor, to assume false titles, or to use language in writings or advertisements implying even remotely that he is legally qualified. It can be proved that similar protection of the medical profession, whilst improving the status of the practitioner, would confer incalculably greater advantages upon the public and especially upon those classes - the weak, the simple, the suffering-who have most claim upon the protection of the State. It would be impossible to legislate effectually against fraudulent practice without dealing at the same time with the traffic in quack medicines. The two trades are inseparably bound up together. It can be demonstrated that the quack medicine trade constitutes a gigantic system of cynical fraud and forms a powerful factor in deterioration of the public health. Very slight modification of existing laws would insure prosecution of most quack medicine proprietors for obtaining money under false pretences and would render amenable newspapers that published their advertisements. Almost complete ignorance of the whole question prevails among the public and among Members of both Houses of Parliament, whilst great prejudice against the profession exists among sections of the public and among certain loud-voiced parties in Parliament. It is impossible that any satisfactory project of medical law reform can obtain a hearing unless taken up by Government. It is extremely improbable that any Bill could be carried without the support of the party in power as well as of the Cabinet and equally improbable that any Government would concern itself with medical reform unless Parliament and the public were first enlightened with regard to the extent of existing evils. The desired enlighten. ment can be brought about through the medium of a Royal Commission and in no other way. Quackery-always including the quack medicine trade-now forms the favoured because safe pursuit of a large section of the vast army of clever cynical tricksters parasitic upon modern society. 'I'hey command large capital and have virtually suborned almost the entire newspaper press either to support them or to remain neutral. With rare exceptions the papers all, from high to low, accept a share of the vast sum, much more than a million sterling annually, disbursed in quack advertisements. No editor dare attack quackery. He can never be certain that a puff, in the form of editorial matter, in praise of an infamous impostor and in disparagement of the profession may not be inserted by his manager in juxtaposition with his article. The story of villainy which could be disclosed before a Royal Commission would astonish and horrify the educated public. It would bring shame to newspaper proprietors, and some of them, perhaps induced by noble lords who own leading papers, might turn away from abetting a nefarious traffic and give their support to medical reform. Whether successful at first or not the Commission would provide a body of conclusive evidence in favour of the legislation demanded, and if this did not in the end lead to provision of the necessary new laws it would be only because the case was for other reasons hopeless. The political influence of the profession as a body is deplorably small, but if properly directed would suffice to achieve the preliminary step which I advocate. Until this step be gained all other effort in the desired direction must prove futile.

London, W., Jan. 26th, 1907. I am, Sirs, yours faithfully,

Childhood Society and the British ChildSTUDY Association.-A course of lectures and discussions has been arranged by the Childhood Society and the British Child.study Association to be delivered in the Parkes Museum, Margaret street, London, W., at 8 P,Mr, on each Thursday up to March 21st. Members and Associates of the two societies will be admitted free of charge; others can attend the lectures by payment of $2 s .6 d$. for the course or $6 d$. for a single lecture. For tickets, applications should be made either to Mr. W. J. Duri ie Mulford, secretary of the Childhood Society, Parkes Museum, or to Kate Stevens, secretary of the British Ohild-study Association, Carlisle House, Dartmouth-park-hill, London, N.W. The next lecture will be delivered by Dr. StClair Thomson on Feb. 14th, the subject being the Care of the Throat, Nose, and Ears in Children. The titles of the subsequent papers and the names of the readers will be as follows: on Feb. 21st, Brain Development through Play, by Mr. J. Arrowsmith; on Feb. 28th, Mental Training in Childhood, by Dr. Robert Jones; on March 7th, Games and Athletics in America, by Mr. T. G. Tibbey; on March 14th, Physical Training in Relation to Fatigue, by Dr. R. J. E. Hanson; and on March 21st, there will be a discussion on Children's Ideal of a Day's Outing. 